\title{
E-COMMERCE DEVELOPMENT IN EUROPE: A PANEL DATA ANALYSIS 2003-2017
}

\section{Alma Lucero Ortiz¹, José Carlos Rodríguez², Mario Gómez}

\author{
1 Universidad Michoacana de San Nicolás de Hidalgo, Economic and Business Research Institute, México, ORCID: \\ 0000-0002-5514-1188, alortiz@umich.mx; \\ 2 Universidad Michoacana de San Nicolás de Hidalgo, Economic and Business Research Institute, México, ORCID: \\ 0000-0002-0942-8017, jcrodriguez@umich.mx; \\ 3 Universidad Michoacana de San Nicolás de Hidalgo, Economic and Business Research Institute, México, ORCID: \\ 0000-0002-4906-0966, mgomez@umich.mx (corresponding author).
}

\begin{abstract}
The Internet is a networking infrastructure that allows people's communication throughout the world, transcending time and space limits. Nowadays, the Internet has changed the way of doing business, leading to a digital economy. Indeed, e-commerce has emerged as commercial transactions conducted over the Internet, which has become a source of economic growth for countries. In this sense, the research question conducting this research is as follows: what are the main variables that have affected the development of e-commerce in European countries from 2003 to 2017? In so doing, panel data econometric methods are used in this research. The tests of cross-section dependence (Pesaran test), unit root (Cross-sectional Im, Pesaran and Shin tests), cointegration (Kao and Fisher-Johansen tests), and heterogeneous causality (Hurlin and Dumitrescu test) are applied. In this regard, the results show that the variables in this research are characterized by a transversal dependence, and that they are integrated of order one. Furthermore, there is evidence that the variables are cointegrated, suggesting that there is a long-term relationship equilibrium between these variables. In addition, there is a bidirectional causality relationship between $R \& D$ spending $(R D)$ and mobile phone penetration (MPP). Also, there is a unidirectional relationship from the development of e-commerce (EC) to $R D$ and from per capita disposable income (PI) to RD. Besides, results suggest a positive and significant effect of $M P P, R D$, and PI on the EC in European developed countries. Therefore, these results show that the CE of the developed countries of Europe could be promoted through the improvement of the $M P P, D R$ and IP.
\end{abstract}

Keywords: Economic growth, e-business, e-commerce, digital economy, econometric model.

JEL Classification: O52, C01.

APA Style Citation: Lucero Ortiz, A., Rodríguez, J. C., \& Gómez, M. (2020). E-commerce Development in Europe: A Panel Data Analysis 2003-2017. E\&M Economics and Management, 23(4), 89-101. https://doi.org/10.15240/tul/001/2020-4-006

\section{Introduction}

In addition to economic factors, other cultural and political influences have been critical drivers of economic growth. Technology issues have begun to feature as a central component of the growth process (Helpman, 1998). For example, technological advances can contribute to humanity's well-being by facilitating a dynamic change, thereby allowing humankind to perform more efficiently (OECD, 1998). The adoption of information technologies, communication infrastructure, and the Internet in multiple social and productive sectors offers tangible advantages to countries. This process has improved several aspects of societies, such as business, technology, education, and the global economy (Ejiaku, 2014). The importance of information and communication technologies (ICTs) as an asset to the economy's growth has been highlighted (Schreyer, 2000).

The way of doing business has been modified using ICTs through different 
processes and tools that allow companies to use Internet-based information technologies. This new type of business practice is called electronic business or e-business (Pilinkiene et al., 2013). E-business refers to using ICTs to support a business strategy using electronic communication tools (Eurostat, 2018). It covers the commercial processes that comprise the entire value chain, mainly from purchasing and logistics management to customer service and alliances with other companies (Eurostat, 2018). E-business is seen as a strategy to improve competitiveness and ensure a competitive advantage, and accordingly, electronic commerce or e-commerce stands out as one of the main activities within e-business (Čiarnienè \& Stankevičiūtè, 2015). E-business can be defined as transactions that are made online, whether commercial or financial and consequently, in some cases, the terms e-business and e-commerce can be used interchangeably (Pilinkiene et al., 2013). For the present study, e-commerce is defined as transactions of goods or services conducted through electronic networks and additional tools such as smart mobile devices and computers (Meng, 2017; OECD, 2018). Importantly, business operations can be conducted between enterprises, households, individuals, governments, and other public or private organizations.

Empirical evidence suggests that ICTs are an essential factor of economic growth and an engine to companies' performance (Cardona et al., 2013). In this regard, the legal framework in industrialized countries has been adapted to the new technological environment, creating confidence that supports e-commerce in these countries. The costs of information about goods, including the place where they are produced and stored and where consumers are located, cause the prices of goods to rise. However, with the introduction of digital information technology, these costs can be reduced, which translates into the rise of e-commerce as a new distribution technology (Cardona et al., 2015). For example, in European countries, online sales are an essential part of companies' total income. Accordingly, in Europe countries, $42 \%$ of large companies made online sales corresponding to $24 \%$ of their total turnover, $28 \%$ of medium-sized companies had online sales corresponding to $13 \%$ of their total turnover, and $17 \%$ of small businesses generated $7 \%$ in online sales compared to their total turnover during the year 2017 (Eurostat, 2019a).

In this regard, this study aims to answer the following research question: what are the main variables that have affected the development of e-commerce in European countries? The objective of this study is to analyze the main variables that have affected the development of e-commerce in European countries during the period 2003-2017. If the variables that have affected e-commerce are understood, tools that promote their development (technological equipment access via computers and smartphones, adequate infrastructure, internet access, and policies) can be proposed.

The variables proposed in this research have begun to be studied only recently. In Europe, more than 75,000 companies use the Internet to sell products and services (Ecommerce Europe, 2019). Nevertheless, firms in these countries still have difficulties selling abroad due to the lack of information, the lack of selfregulation of the digital commerce industry, the lack of confidence among consumers who do not yet have much experience with online shopping, as well as other factors (Ecommerce Europe, 2019). Therefore, there is a lack of studies on these variables that are influencing the growth of e-commerce. The panel data methodology is used in this study. Using panel data, the present study provides reliable results that represent the real behavior of the variables. It contributes to the search for variables that influence e-commerce so that stakeholders can stimulate and manipulate the variables to boost the growth of e-commerce.

This econometric model is carried out using the level of e-commerce (EC) development as a dependent variable, on the one hand, and mobile phone penetration (MPP), research and development spending (RD), and per capita disposable income (PI) as independent variables, on the other. The study sample is made up of the following countries: Belgium, Germany, Ireland, Greece, Spain, Lithuania, Austria, Poland, Portugal, Finland, Sweden, the United Kingdom, and Norway. The period analyzed covers the years from 2003 to 2017 .

In addition to this Introduction, this study is organized into five sections. Section 1 provides a literature review on the general perspective of e-commerce, presenting the central theoretical and empirical research studies. Section 2 discusses the description of the variables used 
in this analysis, the data selection process, and the research hypotheses. Section 3 contains the panel data econometric models computed in this research. Section 4 presents the analysis and discussion of the results. Finally, Section 5 offers the main conclusions.

\section{Literature Review}

Information technologies can make information management processes much more efficient and effective (Ejiaku, 2014). Companies adopt processes and tools that allow them to use Internet-based information technologies to conduct business (Pilinkiene et al., 2013). These technologies play an essential role in sustaining economic growth (Schreyer, 2000). ICTs, for example, defined as any technical means that include computer hardware, networks, or software, are used to access, store, transmit, and manipulate information (Eurostat, 2018). Indeed, they have changed the way of doing business from a traditional model to a new model called e-business (Pilinkiene et al., 2013). In this regard, e-business comprises the business processes along the value chain in which electronic communication tools are used (Eurostat, 2018).

From this perspective, two categories of e-business can be distinguished (Meng, 2017; Čiarnienè \& Stankevičiūtè, 2015). Firstly, e-business is based on the type of business partners, including business to consumer (B2C), consumer to business (C2B), consumer to consumer $(\mathrm{C} 2 \mathrm{C})$, business to business (B2B), government to citizen (G2C), citizen to the government $(\mathrm{C} 2 \mathrm{G})$, government to government (G2G), exchange to exchange (E2E) and intrabusiness or organization unit to organization unit (OUOU). Secondly, e-business is based on the type of business activities involved, such as e-commerce, business intelligence, supply chain management, customer relationship management, enterprise resource planning, electronic marketing, electronic service, and electronic recruitment. In this research, special attention is given to e-commerce.

The OECD (2018) defines e-commerce as a transaction (purchase or sale) of goods or services through computer networks in which payment methods and delivery are not necessarily finalized online. These transactions can be conducted between companies, public or private organizations, households, and other people. A different definition of e-commerce is provided by Meng (2017), who defines e-commerce as the purchase and sale of goods and services, including the transmission of data, funds, and information, through electronic networks, via tools such as smart mobile devices and e-mail. In the present study, e-commerce is defined as transactions of goods or services conducted through electronic networks and supplementary tools, such as smart mobile devices and computers. These transactions can be conducted between enterprises, households, individuals, governments, and other public or private organizations.

There are many studies on the use of ICTs in business (Hollenstein, 2004; OECD, 1998; Ejiaku, 2014), and on e-commerce, as well (Meng, 2017; Pilinkiene et al., 2013; Cardona et al., 2015; Liu, 2013; Wang \& Liu, 2015; Vickery et al., 2004). Schreyer (2000), for example, analyzes the importance of ICTs for different aspects of economic growth: ICT production that focuses on the production process of ICT goods, ICT as a capital input that focuses on the use of ICT in production, and ICT as a particular capital input that benefits not only the investor but also all other participants improving overall productivity and promoting income growth.

Pilinkiene et al. (2013) study the relationship between the benefits of e-business and competitive advantage, analyzing the impact of e-business on the usual business processes from a resource-based perspective (Barney, 1991; Barney et al., 2001; Barney et al., 2011) and Porter's approach (1980) to competitive advantage. These authors use the competitive advantage as the dependent variable and reliable infrastructure, inbound logistics, technology development, marketing and sales, outbound logistics, operations, human resource management, service, and procurement as the independent variables. They found that e-business has a positive impact on several business processes, but its benefits do not necessarily lead to an increase in profits or sales. In the same way, Čiarnienè and Stankevičiūtè (2015) propose a theoretical framework of competitiveness for e-businesses through developing a conceptual model in which the competitiveness of e-commerce is featured as one of the main activities of e-business. The analysis is carried out at a company level, industry level, country level, and global level. They argue that five main dimensions have an essential effect on the 
competitiveness of e-commerce at a country level, including macroeconomics, market, socio-cultural aspects, technology, and the role of governments.

Cardona et al. (2015) examine the economic impact of e-commerce as a new technology to perform B2C transactions (purchases and sales) online to reduce commercial costs. Their study was carried out in the European Union Digital Single Market. Their research evaluates the impact of the balance between technological shock and the policy shock regarding regulatory measures when e-commerce comes to reduce new sources of online trade costs. They found that e-commerce has a positive impact on the economy. Liu (2013) researches the impact of e-commerce on national economic growth in China using an econometric model. This study concludes that e-commerce can help promote economic growth. Besides, e-commerce is approached as an independent variable through indicators of investment, government purchases, consumption, and net exports. It is approached as a dependent variable vis-à-vis the level of economic development measured by gross domestic product (GDP).

Wang and Liu (2015) study the factors that affect e-commerce development in China. In their research, they used a partial least squares regression model to analyze times series data from 2000 to 2012. As a dependent variable, the proportion of e-commerce turnover that accounted for GDP was used. The independent variables in this study include Internet penetration, number of computers, number of websites, mobile phone penetration, real GDP per capita, knowledge index, urbanization rate, research and development spending as a share of GDP, number of patent applications, per capita disposable income, proportionbased employment of information industry, and communication price index. They found that mobile phone penetration, the number of computers, per capita disposable income, real GDP per capita, knowledge index, and Internet penetration are critical factors affecting e-commerce development. In these and other studies, it can be seen that the use of ICTs in business is actively being researched, with e-commerce being increasingly related to economic development.

Bhowmik (2017) conducted an econometric study of total retail sales from e-commerce in India during the 2005-2020. Using retail sales in e-commerce, the number of credit and debit cardholders, and the percentage of the population who are Internet users as independent variables, this study treats the GDP growth rate as the dependent variable. The study used a double log multiple regression model, the Granger causality test (Granger, 1969), and the Johansen cointegration test (Johansen, 1988). The results suggest that trade in India is growing fast enough. However, this country needs to improve the infrastructure required for this type of trade by implementing

\section{Fig. 1: Relationship between the variables}

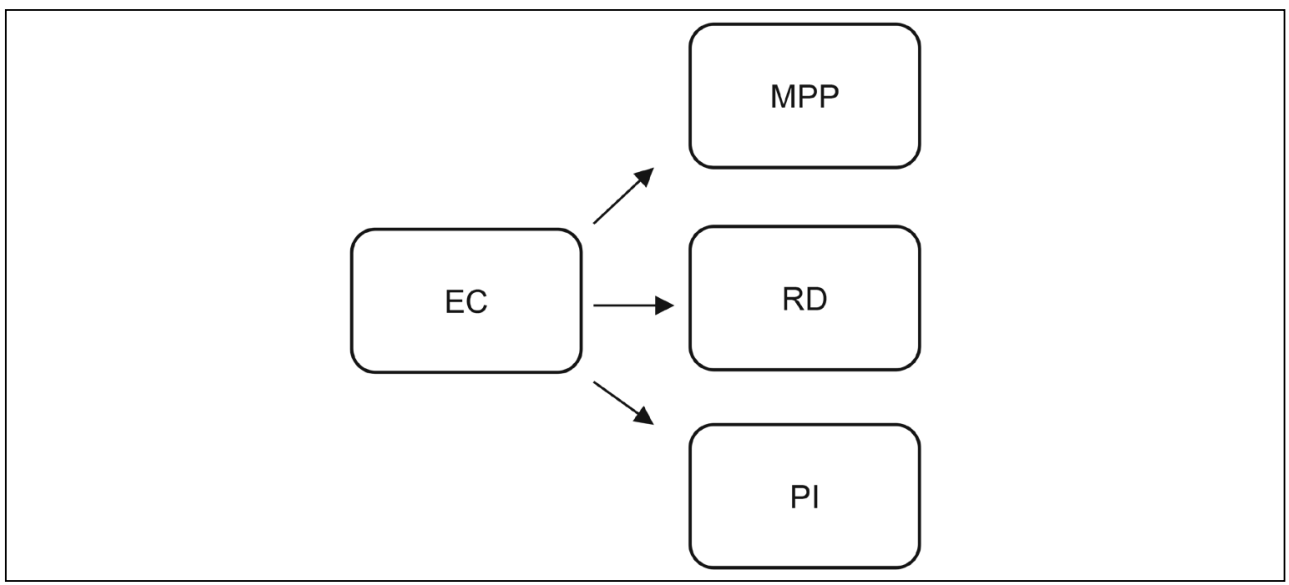


greater electronic security, managing customs control, and imposing electronic taxes and other regulatory measures.

Liu et al. (2013) conducted a panel data study on the impact of e-commerce and research and development spending (RD) on Taiwanese manufacturing companies' productivity for 1999-2002. In their results, they found that both e-commerce and RD capital have a positive influence on productivity, with the $R D$ variable having a more significant effect. It was also found that there is a complementary relationship between e-commerce and $\mathrm{RD}$ for productivity improvement.

The present study aims to get insight into the main variables that impact the development level of e-commerce in European countries. Following Wang and Liu (2015), the variables in Fig. 1 were considered in the model computed in this research. The question conducting this study is as follows: the variables MPP, RD, and $\mathrm{PI}$ have had a positive influence on the development of e-commerce in European countries during the period 2003-2017? The model proposed in this study aims to get insight into the relationships between e-commerce and the main variables that are believed to have affected its level of development.

\section{Methodology}

The objective of this study is to identify the main variables that have affected the development of e-commerce in European countries. E-commerce emerged with the arrival of ICTs to business as one of its business processes (Čiarnienè \& Stankevičiūtè, 2015). For this research, e-commerce is defined as the transactions of goods or services conducted through electronic networks and other supplementary tools such as smart mobile devices and computers (OECD, 2018; Meng, 2017).

\subsection{Variables, Data Collection and Hypotheses}

$\mathrm{E}$-commerce is an issue that has gained much importance today. However, it was not until the years after the appearance of the Internet that some countries began to collect data on its use. For this reason, data availability is an essential limitation for studies of this issue. Variables such as internet penetration, number of computers in households, number of websites per person, knowledge index, urbanization rate, and jobs in the information industry have been typically considered for many studies (Wang \& Liu, 2015). However, this study analyses EC as the dependent variable, and MPP, RD spending, and $\mathrm{PI}$ as independent variables.

\section{Tab. 1: Variables and data collectio}

\begin{tabular}{|c|c|c|c|}
\hline Indicator & Definition & Measurement & Source \\
\hline \multicolumn{4}{|c|}{ Dependent variable } \\
\hline EC & $\begin{array}{l}\text { The total turnover of the } \\
\text { companies from e-commerce }\end{array}$ & $\begin{array}{l}\text { The percentage of } \\
\text { enterprises' total turnover } \\
\text { from e-commerce }\end{array}$ & Eurostat (2019a) \\
\hline \multicolumn{4}{|c|}{ Independent variables } \\
\hline MPP & $\begin{array}{l}\text { Subscriptions to a public } \\
\text { mobile telephone service } \\
\text { using cellular technology } \\
\text { (WB, 2018) }\end{array}$ & $\begin{array}{l}\text { The number of subscriptions } \\
\text { to a public mobile telephone } \\
\text { service per } 100 \text { people }\end{array}$ & WB (2018b) \\
\hline $\mathrm{RD}$ & $\begin{array}{l}\text { Gross domestic expenditures } \\
\text { on research and } \\
\text { development (percentage of } \\
\text { GDP) (WB, 2018) }\end{array}$ & $\begin{array}{l}\text { The percentage of GDP } \\
\text { devoted to research and } \\
\text { development (RD) spending } \\
\text { in each country }\end{array}$ & $\begin{array}{l}\text { WB }(2018 c), \\
\text { Eurostat }(2019 b)\end{array}$ \\
\hline $\mathrm{Pl}$ & $\begin{array}{l}\text { Gross national income (GNI) } \\
\text { minus consumption of fixed } \\
\text { capital and natural resource } \\
\text { depletion (WB, 2018) }\end{array}$ & $\begin{array}{l}\text { Per capita disposable income } \\
\text { from each country (constant: } \\
\qquad 2010 \text { USD) }\end{array}$ & WB (2018a) \\
\hline
\end{tabular}




\section{Business Administration and Management}

On the other hand, the sample considered in this research is the European countries that meet the following characteristics:

- Industrialized countries (UN, 2014);

- Countries with the highest percentage of Internet users (WB, 2020);

- Data availability.

Consequently, data collection was made from Belgium, Germany, Ireland, Greece, Spain, Lithuania, Austria, Poland, Portugal, Finland, Sweden, the United Kingdom, and Norway for the period 2003-2017. Indeed, countries that met these characteristics are mainly those from the European Union, except for Norway and the United Kingdom. Data was taken from Eurostat (2019a, 2019b) and WB (2018a, 2018b, 2018c). Tab. 1 shows the variables of this study, definitions, measure unites, and sources.

Fig. 2 shows the graph of the data referring to e-commerce from the 13 countries in the sample during 2003-2017. All countries show a positive trend, while the countries that have had a higher turnover rate of companies dedicated to e-commerce during recent years have been Ireland, Belgium, Norway, Sweden, Finland, the United Kingdom, Portugal, and Spain. Belgium's growth stands out, which went from $7 \%$ in 2003 to $32 \%$ in 2017 . Meanwhile, Greece shows the weakest turnover, which went from $2 \%$ in 2003 to $4 \%$ in 2017.

For the EC indicator, the information of all companies with ten or more employees was considered, not including the financial sector. As part of the infrastructure for developing the ICTs, broadband Internet was included in the initial model. However, this variable did not prove to be relevant to the model. Therefore, the following hypotheses were stated:

H1: MPP has a positive effect on EC.

H2: RD has a positive effect on EC.

H3: PI has a positive effect on EC.

\section{Econometric Models}

Regression analysis deals with the study of the dependence of a variable concerning one or more explanatory variables (Gujarati \& Porter, 2010). This study analyzes the relationship between a dependent variable and other independent variables in a linear model as follows:

$$
\begin{aligned}
& \mathrm{EC}_{i t}=\text { constant }+\beta_{0 i t}+\beta_{1 \mathrm{i}} M P P_{i t}+ \\
& +\beta_{2 \mathrm{i}} R D_{i t}+\beta_{3 \mathrm{i}} P I_{i t}+e_{i t}
\end{aligned}
$$

\section{Fig. 2: Total turnover of the companies from e-commerce (percentage)}

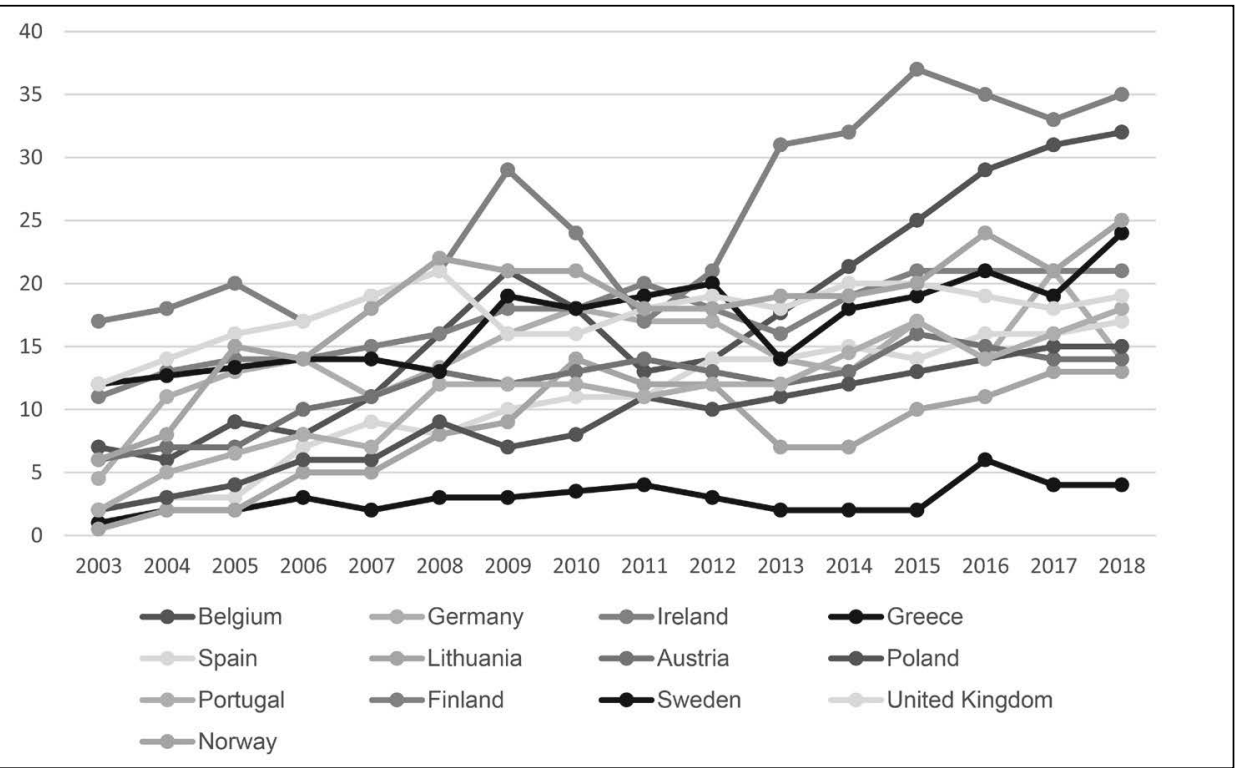

Source: data from Eurostat (2019a, 2019b) and WB (2018a, 2018b, 2018c) 
where EC is the dependent variable, and MPP, $\mathrm{RD}$ and $\mathrm{PI}$ are the explanatory or independent variables, with $i$ indicating the cross-section (the thirteen countries), $t$ representing the time period of the data, and $e_{i}$ representing the error term. The parameters $\beta_{1}, \beta_{2}$ and $\beta_{3}$ represent the long-term relationship between MPP, $\mathrm{RD}$, and $\mathrm{PI}$ and the dependent variable $\mathrm{EC}$. Accordingly, it is expected that $\beta_{1}>0$, because the increase in mobile phone users generates a new means to make purchases through the Internet, implying that e-commerce grows. Similarly, the expenditure variable in research and development represents the country's technological level, and thus, it is expected that the more technologically advanced the country is, the greater the boost to e-commerce. Hence, it is expected that $\beta_{2}>0$. Finally, it is expected that $\beta_{3}>0$ because the variable per capita disposable income reflects the standard of living of people in a country. Therefore, the higher the people's income, the more purchases they make, which boosts the development of e-commerce.

Panel data estimation techniques explicitly consider the presence of heterogeneity. They also provide more informative data, less collinearity between variables, higher efficiency, and more degrees of freedom. Besides, they are more appropriate for studying the dynamics of change (Baltagi, 1995). However, time series can give spurious regressions. To avoid getting invalid results, it is essential to perform several tests and verify whether there is a long-term relationship between variables.

It is assumed that perturbations in the panel data models are transversally independent. In this regard, it is crucial to apply the cross-section dependence $(C D)$ test to confirm whether there is such a dependence between variables (Pesaran, 2004). If there is a dependency, unit root tests that generate consistent results in the absence of independence should be applied (Riti et al., 2017).
When variables are cointegrated, OLS methods might produce biased and inconsistent results. A method called Fully Modified OLS (FMOLS) is applied to avoid inconsistent estimates (Pedroni, 2001; Kao \& Chiang, 2001). The advantage of using the FMOLS estimator is that this test behaves relatively well even when working with small samples. It also generates consistent estimates, and it allows for control of the serial correlation and the endogeneity of its regressors (Pedroni, 2001). Therefore, the present study uses the FMOLS estimators for cointegrated heterogeneous panels.

If the variables are cointegrated, there must be a causal relationship in at least one direction (Granger, 1988). To determine the existence of some causal relationship between the variables, it is necessary to apply a causality test. This research uses the proposal of Dumitrescu and Hurlin (2012) to prove causality in panel data models that are heterogeneous both in terms of the causal relationship at issue and in terms of the regression model used. This test performs well in small samples.

\section{Analysis of Results}

For the analysis of the variables, a panel data model is applied using annual data from European countries from 2003 to 2017. First, the CD test was performed. The results of the test are presented in Tab. 2. They suggest that the null hypothesis of non-dependence is rejected for all variables at a level of significance of $1 \%$, which means that there is a transversal dependency in all the variables, and the variables of each country are correlated with each other.

To generate consistent results in the presence of such cross-section dependence, it is necessary to apply a second-generation panel unit root test like the Cross-sectional Augmented Dickey-Fuller (CADF) or the Cross-sectional Im, Pesaran and Shin (CIPS) tests. For this study, the CIPS panel unit root

\section{Tab. 2: Pesaran test for cross-sectional dependence}

\begin{tabular}{l|c|c|c|c}
\multicolumn{1}{c|}{ Variable } & EC & MPP & RD & PI \\
\hline Pesaran CD statistic & $25.070^{\star \star *}$ & $26.526^{\star \star *}$ & $11.027^{\star \star *}$ & $10.888^{\star \star *}$ \\
\hline P-value & 0.000 & 0.000 & 0.000 & 0.000 \\
\hline
\end{tabular}


Tab. 3: CIPS panel unit root test

\begin{tabular}{l|c|c}
\multicolumn{1}{c|}{ Variable } & Deterministic parameters & CIPS \\
\hline $\mathrm{EC}$ & $\mathrm{CT}$ & -2.268 \\
\hline $\mathrm{MPP}$ & $\mathrm{CT}$ & -1.452 \\
\hline $\mathrm{RD}$ & $\mathrm{CT}$ & -2.073 \\
\hline $\mathrm{PI}$ & $\mathrm{CT}$ & -1.456 \\
\hline \multicolumn{3}{|c}{ First difference } \\
\hline$\Delta \mathrm{EC}$ & $\mathrm{C}$ & $-3.819^{* * *}$ \\
\hline$\Delta \mathrm{MPP}$ & $\mathrm{C}$ & $-2.445^{* *}$ \\
\hline$\Delta \mathrm{RD}$ & $\mathrm{C}$ & $-3.334^{* \star}$ \\
\hline$\Delta \mathrm{PI}$ & $\mathrm{C}$ & $-2.625^{\star \star *}$ \\
\hline
\end{tabular}

Source: own

Note: ${ }^{* *}$ and ${ }^{* *}$ denote the rejection of the null hypothesis at the $1 \%$ and $5 \%$ levels. C denotes constant; CT denotes constant and trend.

test, proposed by Pesaran (2007) is used. The results are presented in Tab. 3 and confirm that the variables are integrated into order one, which implies that all the variables have unit roots in the levels, but that they are stationary in the first differences at a $1 \%$ and $5 \%$ level of significance.

The regression of a time series variable on one or more time-series variables can give spurious results. It must be established whether the time series are cointegrated to avoid this (Gujarati \& Porter, 2010). Once it is confirmed that the variables are stationary in first differences, the test of the presence of a long-term relationship between the integrated variables can be performed. Accordingly, the cointegration Kao test (1999) and the Fishertype test using Johansen's (1988) methodology are applied. The results for the Kao test are shown in Tab. 4. The null hypothesis of noncointegration is rejected at a significance level of $1 \%$, which indicates that the variables have a long-term relationship between them.
Tab. 5 shows the results of the FisherJohansen cointegration test, which reveals that there are at least three cointegration relationships. Since the null hypothesis is rejected at a $1 \%$ level of significance. The test confirms the existence of a long-term relationship between variables.

When it is known that the panel data model variables are cointegrated, OLS's method turns out to be inadequate because it can produce inconsistent estimates. Therefore, the study relies on a new method for estimating cointegration relationships using panel data: namely, the FMOLS estimator (Pedroni, 2001; Kao \& Chiang, 2001). FMOLS estimators generate consistent estimates and perform well in small samples (Pedroni, 2001).

Accordingly, this research uses FMOLS estimators for cointegrated heterogeneous panels. In Tab. 6 , it can be seen that, with FMOLS estimators, all the variables are statistically significant at $1 \%$ and $5 \%$ levels of significance. The long-term coefficients show

\section{Tab. 4: Results of the Kao cointegration test}

\begin{tabular}{l|c}
\multicolumn{1}{c|}{ Test } & T-statistic \\
\hline Augmented Dickey-Fuller (ADF) & $-3.741645^{\star * *}$ \\
\hline P-value & $(0.0001)$ \\
\hline
\end{tabular}

Note: ${ }^{* * *}$ denotes the rejection of the null hypothesis at the $1 \%$ level. 
Tab. 5: Results of the Fisher-Johansen cointegration test

\begin{tabular}{c|c|c} 
Null hypothesis & Trace test & Max-Eigen test \\
\hline$R=0$ & $482.3^{\star \star \star}$ & $344.7^{\star \star \star}$ \\
\hline$R \leq 1$ & $188.1^{\text {**}}$ & $134.1^{\star \star *}$ \\
\hline$R \leq 2$ & $78.80^{\star \star *}$ & $52.25^{\text {**}}$ \\
\hline$R \leq 3$ & $56.42^{\star \star *}$ & $56.42^{\text {***}}$ \\
\hline
\end{tabular}

Source: own

Note: $\mathrm{R}$ indicates the number of cointegrating relations.

${ }^{* * *}$ denotes the rejection of the null hypothesis at the $1 \%$ level.

a positive relationship between the $\mathrm{EC}$ and MPP variables, which implies that the higher the number of mobile phone users, the greater the growth of e-commerce. A critical technological advance has been the development of mobile e-commerce, or online sales with the potential for companies and users to perform various tasks related to trade without time and location (Tarasewich et al., 2002). This development implies that the use of mobile phones has a positive impact on e-commerce.

For the variable RD, the results show a positive relationship between $E C$ and $R D$, which means that the higher the spending on research and development, the greater the growth of e-commerce. Zhu (2004) studied the relationship between information technology (IT) infrastructure and e-commerce, finding a strong positive effect between the IT infrastructure and e-commerce. This finding suggests that IT contributes positively to the company's performance in terms of sales per employee, inventory rotation, and cost reduction. Overall, then, it can be inferred that advances in technology have a positive impact on e-commerce.

Finally, the results suggest a positive relationship between the variables $\mathrm{EC}$ and $\mathrm{PI}$, which means that the higher the per capita disposable income, the greater the growth of e-commerce. In this research, per capita disposable income is an indicator of the standard of living of the citizens of a country. The OECD (2018) defines PI as the amount of money that a household earns each year; it represents the money available for a household to spend on goods or services. The positive effect of the variable $\mathrm{PI}$ concerning e-commerce can be explained as follows: the higher the income of a family, the greater the purchasing power it has, allowing it to make more purchases by any means. Besides, a higher purchasing power allows access to products and services such as computers, mobile phones, the Internet, and higher education, among others. Such access facilitates e-commerce.

Since there was a long-term relationship between the variables, it needs to be determined whether there is a causal relationship in at least one direction. Therefore, the Granger causality test was applied. Tab. 7 contains the results of the causality test, which indicates that, in the long term, there is a causal relationship from MPP, RD, and PI to EC with a level of significance of $1 \%$. Also, there is a causal

\section{Tab. 6: Estimation of long-term coefficients}

\begin{tabular}{l|c|c}
\multicolumn{1}{c|}{ Variable } & FMOLS coefficients & P-value \\
\hline MPP & 0.074975 & $0.0114^{\text {** }}$ \\
\hline RD & 5.524683 & $0.0048^{\text {** }}$ \\
\hline PI & 0.000469 & $0.0082^{\text {** }}$ \\
\hline
\end{tabular}

Note: ${ }^{* * *}$ and ${ }^{* *}$ denote statistical significance at the $1 \%$ and $5 \%$ levels, respectively. 
Tab. 7: Granger causality test results

\begin{tabular}{l|c|c|c|c|c}
\multirow{2}{*}{$\begin{array}{c}\text { Dependent } \\
\text { variables }\end{array}$} & \multicolumn{4}{|c|}{ Short run } & Long run \\
\cline { 2 - 6 } & $\Delta \mathrm{EC}$ & $\Delta$ MPP & $\Delta$ RD & $\Delta$ PI & ECT-1 \\
\hline EC & - & $0.044000^{* * *}$ & 0.024975 & 0.010324 & $-0.013986^{* * *}$ \\
\hline MPP & $0.818052^{* * *}$ & - & 0.021890 & 0.044699 & -0.000593 \\
\hline RD & 0.222612 & 0.011691 & - & -0.002877 & $-0.003812^{* *}$ \\
\hline PI & $1.207445^{\star * *}$ & $0.221250^{* *}$ & 0.022962 & - & $0.002736^{* * *}$ \\
\hline
\end{tabular}

Source: own

Note: ${ }^{* * *}$ and ${ }^{* *}$ denote statistical significance at the $1 \%$ and $5 \%$ levels, respectively. ECT- 1 denotes the estimated coefficient of the lagged error correction term.

relationship from EC, MPP, and PI to RD. In the short term, the results suggest that there is a bidirectional causal relationship between the variables EC and MPP at the $1 \%$ level of significance. Also, there is a unidirectional causal relationship from EC to $\mathrm{PI}$, at the $1 \%$ level of significance, and a unidirectional causal relationship from MPP to $\mathrm{PI}$, at the $5 \%$ level of significance.

Dumitrescu and Hurlin's (2012) test for causality in a heterogeneous panel data model is used to consider potential problems related to the heterogeneity of cross-sectional units in econometrics panel data. The results for the heterogeneous causality test are presented in
Tab. 8. As can be seen, there is a bidirectional causal relationship between RD and MPP at $1 \%$ and $5 \%$ levels of significance. Also, there is a unidirectional relationship from EC to RD and $\mathrm{PI}$ to $\mathrm{RD}$, both at the $1 \%$ level of significance.

\section{Conclusions}

The objective of this research was to study the main variables that have affected the development of e-commerce in European countries, considering that e-commerce serves as a source of economic growth for the countries. As a dependent variable, the EC was selected. The independent variables for the study were MPP, RD, and PI. Data were

\section{Tab. 8: Results of the heterogeneous causality test}

\begin{tabular}{l|l|l}
\multicolumn{1}{c|}{ Null hypothesis } & Wald test & Decision \\
\hline MPP does not homogeneously cause EC & 1.39025 & Accept \\
\hline EC does not homogeneously cause MPP & 2.00051 & Accept \\
\hline PI does not homogeneously cause EC & 1.79285 & Accept \\
\hline EC does not homogeneously cause PI & 1.78306 & Accept \\
\hline RD does not homogeneously cause EC & 1.22338 & Accept \\
\hline EC does not homogeneously cause RD & $3.20692^{* * *}$ & Reject \\
\hline PI does not homogeneously cause MPP & 1.76908 & Accept \\
\hline MPP does not homogeneously cause PI & 1.95493 & Accept \\
\hline RD does not homogeneously cause MPP & $2.35453^{* *}$ & Reject \\
\hline MPP does not homogeneously cause RD & $7.96426^{* * *}$ & Reject \\
\hline RD does not homogeneously cause PI & 1.46864 & Accept \\
\hline PI does not homogeneously cause RD & $7.08963^{* * *}$ & Reject \\
\hline
\end{tabular}

Note: ${ }^{* * *}$ and ${ }^{* *}$ denote the rejection of the null hypothesis at the $1 \%$ and $5 \%$ levels, respectively. 
collected from sources such as Eurostat and WB. Due to the availability of these data, panel data were built to cover the period 2003-2017.

For the analysis, a cross-section dependence test, second-generation unit root tests, and cointegration tests were applied. Results for the CD cross-section dependence test suggest that there is a transversal dependency in all the variables and that each country's variables are correlated with each other at a level of significance of $1 \%$. Hence, to generate consistent results, a CIPS panel unit root test was performed. The results confirm that the variables are integrated into order one, which means that all the variables have unit roots in the levels, but they are stationary in the first differences at a $1 \%$ and $5 \%$ level of significance. Besides, it is confirmed that there is a long-term relationship between variables. The FMOLS estimator showed the following results: a positive relationship between the EC and MPP, which implies that the higher the number of mobile phone users, the greater the growth of e-commerce; a positive relationship between $E C$ and RD, which means that the higher the spending on research and development, the greater the growth of e-commerce; and, finally, a positive relationship between the variables $\mathrm{EC}$ and $\mathrm{PI}$, which means that the higher the per capita disposable income, the greater the growth of e-commerce. Shortly speaking, the hypotheses of this research can be accepted in that MPP, RD and PI have a positive effect on EC.

The main contribution of this paper is that the analyzed independent variables have a positive effect on the development of e-commerce in the group of European countries studied. $\mathrm{E}$-commerce is the product of technological advances in a digital age; therefore, developed countries create an environment that favors the development of e-commerce via greater purchasing power, higher educational levels, more robust policies to ensure the safety of users of e-commerce, and more significant infrastructure for IT, among other factors. The limitations of the article stem from the limited availability of information: it was not until after 2000 that records of ICT within businesses began to be compiled. In future research, the model outlined here needs to be extended to the study to developing countries, to facilitate a comparative analysis of these countries.

\section{References}

Baltagi, B. H. (1995). Econometric Analysis of Panel Data (1st ed.). New York, NY: John Wiley and Sons.

Barney, J. (1991). Firm resources and sustained competitive advantage. Journal of Management, 17(1), 99-120. https://doi. org/10.1177/014920639101700108

Barney, J., Ketchen, D., \& Wright, M. (2011). The future of resource-based theory: Revitalization or decline? Journal of Management, 37(5), 1299-1315. https://doi. org/10.1177/0149206310391805

Barney, J., Wright, M., \& Ketchen, D. J. (2001). The resource-based view of the firm: Ten years after 1991. Journal of Management, 27(6), 625-641. https://doi. org/10.1177/014920630102700601

Bhowmik, D. (2017). India's retail sales of e-commerce: An econometric analysis. International Journal of Scientific and Research Publications, 7, 13-21.

Cardona, M., Kretschmer, T., \& Strobel, T. (2013). ICT and productivity: conclusions from the empirical literature. Information Economics and Policy, 25(3), 109-125. https://doi. org/10.1016/j.infoecopol.2012.12.002

Cardona, M., Duch-Brown, N., Francois, J., Martens, B., \& Yang, F. (2015). The macroeconomic impact of e-commerce in the EU Digital Single Market (Working Paper 2015/09). Joint Research Centre (JRC), European Commission, Institute for Prospective Technological Studies Digital Economy.

Čiarnienè, R., \& Stankevičiūtè, G. (2015). Theoretical framework of e-business competitiveness. Procedia - Social and Behavioral Sciences, 213, 734-739. https://doi. org/10.1016/j.sbspro.2015.11.528

Dumitrescu, E.-I., \& Hurlin, C. (2012). Testing for Granger non-causality in heterogeneous panels. Economic Modelling, 29(4), 1450-1460. https://doi.org/10.1016/j. econmod.2012.02.014

Ejiaku, S. A. (2014). Technology adoption: Issues and challenges in information technology adoption in emerging economies. Journal of International Technology and Information Management, 23(2), 59-68.

Eurostat. (2018). Glossary. Retrieved December 4, 2018, from https://ec.europa. eu/Eurostat/statistics-explained/index.php/ Glossary:Information_and_communication_ technology_(ICT) 
Eurostat. (2019a). E-commerce statistics. Retrieved April 16, 2019, from https://ec.europa. eu/Eurostat/statistics-explained/index.php/Ecommerce_statistics online publications

Eurostat. (2019b). E-commerce statistics. Retrieved April 16, 2019, from https://ec.europa.eu/Eurostat/tgm/table. do tab $=$ table \&init=1 \& plugin=1\&language $=$ en\&pcode=t2020_20

Granger, C. W. J. (1969). Investigating causal relations by econometric models and cross-spectral methods. Econometrica, 37(3), 424-438. https://doi.org/10.2307/1912791

Granger, C. W. J. (1988). Some recent development in a concept of causality. Journal of Econometrics, 39(1-2), 199-211. https://doi. org/10.1016/0304-4076(88)90045-0

Gujarati, D. N., \& Porter, D. C. (2010). Econometría (5th ed.). México: McGraw-Hill Interamericana.

Haenlein, M., \& Kaplan, A. M. (2004). A beginner's guide to partial least squares analysis. Understanding Statistics, 3(4), 283-297. https://doi.org/10.1207/s15328031us0304_4

Helpman, E. (1998). General purpose technologies and economic growth. Cambridge, MA: The MIT Press.

Hollenstein, H. (2004). Determinants of the adoption of Information and Communication Technologies (ICT): An empirical analysis based on firm-level data for the Swiss business sector. Structural Change and Economic Dynamics, 15(3), 315-342. https://doi.org/10.1016/j. strueco.2004.01.003

Johansen, S. (1988). Statistical analysis of cointegration vectors. Journal of Economic Dynamics and Control, 12(2-3), 231-254. https://doi.org/10.1016/0165-1889(88)90041-3

Kao, C. (1999). Spurious Regression and Residual Based Tests for Cointegration in Panel Data. Journal of Econometrics, 90(1), 1-44. https://doi.org/10.1016/S0304-4076(98)00023-2

Kao, C., \& Chiang, M. H. (2001). On the estimation and inference of a cointegrated regression in panel data. In B. H. Baltagi, T. B. Fomby, \& R. Carter (Eds.), Nonstationary Panels, Panel Cointegration, and Dynamic Panels (Advances in Econometrics, Vol. 15) (pp. 179-222). Bingley: Emerald Group Publishing Limited. https://doi.org/10.1016/ S0731-9053(00)15007-8

Liu, S. (2013). An empirical study on e-commerce's effects on economic growth. Paper presented at International Conference on Education Technology and Management Science (ICETMS 2013). https://doi. org/10.2991/icetms.2013.260

Liu, T. K., Chen, J. R., Huang, C., \& Yang, C. H. (2013). E-commerce, R\&D, and productivity: Firm-level evidence from Taiwan. Information Economics and Policy, 25(4), 272-283. https://doi.org/10.1016/j.infoecopol.2013.07.001

Meng, T. (2017). National Report on e-commerce development in UK (Inclusive and Sustainable Industrial Development Working Paper Series WP 19|2017). Vienna: United Nations Industrial Development Organization.

OECD. (1998). 21st Century technologies promises and perils of a dynamic future. Retrieved December 4, 2018, from https://www. oecd.org/futures/35391210.pdf

OECD. (2018). Glossary of statistical terms. Retrieved December 4, 2018, from https://stats. oecd.org/glossary/detail.asp?ID=4721

OECD. (2019). Income. Retrieved April 18, 2019, from http://www.oecdbetterlifeindex.org/ topics/income/

Pedroni, P. (2001). Fully modified OLS for heterogeneous cointegrated panels. In B. H. Baltagi, T. B. Fomby, \& R. Carter (Eds.), Nonstationary Panels, Panel Cointegration, and Dynamic Panels (Advances in Econometrics, Vol. 15) (pp. 93-180). Bingley: Emerald Group Publishing Limited.

Pesaran, M. H. (2004). General Diagnostic Test for cross section dependence in panels (Discussion Paper No. 1240). Bonn: Institute for the Study of Labor. Retrieved April 12, 2018, from http://ftp.iza.org/dp1240.pdf

Pesaran, M. H. (2007). A simple panel unit root test in the presence of cross-section dependence. Journal of Applied Econometrics, 22(2), 265-312. https://doi.org/10.1002/jae.951

Pilinkiene, V., Kurschus, R.-J., \& Auskalnyte, G. (2013). E-business as a source of competitive advantage. Economics and management, 18(1), 77-85. https://doi. org/10.5755/j01.em.18.1.3669

Porter, M. (1980). Competitive Strategy. New York, NY: Free Press.

Riti, J. S., Song, D., Shu, Y., \& Kamah, M. (2017). Decoupling CO2 emission and economic growth in China: Is there consistency in estimation results in analyzing environmental Kuznets curve? Journal of Cleaner Production, 166, 1448-1461. https://doi.org/10.1016/j.jclepro.2017.08.117

Schreyer, P. (2000). The Contribution of Information and Communication Technology 
to Output Growth: A Study of the G7 Countries (OECD Science, Technology and Industry Working Paper No. 2000/02). Paris: OECD Publishing. https://doi. org/10.1787/151634666253

Tarasewich, P., Nickerson, R. C., \& Warkentin, M. (2002). Issues in mobile e-commerce. Communications of the Association for Information Systems, 8, 41-64. https://doi.org/10.17705/1CAIS.00803

UN. (2014). Country classification, World Economic Situation and Prospects 2014. Retrieved July 19, 2020, from https://www.un.org/en/development/desa/ policy/wesp/wesp_current/2014wesp_country_ classification.pdf

Vickery, G., Sakai, K., Lee, I., Sim, H., \& Faverie, M. (2004). ICT, E-business and SMEs. Organisation for Economic Co-operation and Development. Retrieved October 2, 2018, from http://www.oecd.org/cfe/smes/31919255.pdf

Wang, X., \& Liu, L. (2015). Empirical research on the influence factors of e-commerce development in China. The Open Cybernetics \& Systemics Journal, 9, 76-82. https://doi. org/10.2174/1874110X01509010076
WB. (2018a). World Bank national accounts data, and OECD National Accounts data files. Retrieved December 5, 2018, from https://data. worldbank.org/indicator/NY.ADJ.NNTY.PC.KD

WB. (2018b). World Bank national accounts data, and OECD National Accounts data files. Retrieved December 6, 2018, from https://data. worldbank.org/indicator/IT.CEL.SETS.P2

WB. (2018c). World Bank national accounts data, and OECD National Accounts data files. Retrieved December 7, 2018, from https://data. worldbank.org/indicator/GB.XPD.RSDV.GD.ZS

WB. (2020). World Bank data, Individuals using the Internet (\% of population). Retrieved July 19, 2020, from https://data.worldbank.org/ indicator/IT.NET.USER.ZS?view=map.

Zhu, K. (2004). The Complementarity of Information Technology Infrastructure and E-Commerce Capability: A Resource-Based Assessment of Their Business Value. Journal of Management Information Systems, 21(1), 167-202. Retrieved from https://rady.ucsd.edu/ faculty/directory/zhu/docs/papers/paper10_ JMIS_Complementarity.pdf 